\title{
農村地域の高齢者支援ネットワークと居住継続に関する考察 \\ - 輪島市門前町道下の場合 - \\ SENIOR CITIZEN SUPPORT NETWORK IN RURAL VILLAGE REGION \\ AND CONSIDERATION CONCERNING RESIDENCE CONTINUANCE
}

In case of Touge village in Monzen cho, Wajima city

中川和 樹*, 山崎寿一**

Kazuki NAKAGAWA and Juichi YAMAZAKI

\begin{abstract}
Wajima City Monzen town Touge is maintaining the number of households though is one of the mountainous village regions where depopulation and aging become problems. The factor that the senior citizen keeps residing in the village includes the existence of the senior citizen support network. In the senior citizen support network, two or more things etc. by the relative by the one, the one by the friend, and the welfare commissioner exist. The environment that the senior citizen lives easily is made because two or more support networks accumulate, and the residence of an aged home is continued.
\end{abstract}

Keywords : rural village region, , Depopulation aged problem, Senior citizen support network, Residence

continuance, Village maintenance

農村地域，過疎高齢問題，高齢者支援ネットワーク，居住継続，集落維持

\section{1. 研究の背景 - 目的 - 方法}

2007 年 3 月 25 日に発生した能登半島地震は過疎高齢化が進む農 村地域での震災と位置づけられる。筆者は震災直後より住宅被害と 復興状況を把握すべく最大被災地である輪島市門前町道下 (とうげ) にて現地調查を開始し、被災集落の住宅復興の実態と地域的な特徵 について既に報告している注1) 注2)。このなかで、当初震災による過 疎化・高齢化の促進が危惧されたが高齢世帯も復興を果たし、集落 での居住を継続していることも指摘した。道下は約 300 戸から成る 農村集落であるが、周辺集落が世帯数減少・過疎化を進行させる中、 人口減少が見られ始めた 1970 年以降も世帯数をほぼ維持している注 3)。道下集落の世帯数維持、高齢者の居住継続には、家を維持して 地域に住み続けたいという意識と共に高齢者が安心して暮らしてい ける支援ネットワークの存在と関わりがあるのではないか、と考え るに至った。本稿では高齢者が安心して居住継続できる諸要件の解 明という問題意識から、研究を進めることにする。

登張注 4) らは、農村高齢者の生活と地縁に着目し、生活行動・人 間関係の多様性を明らかにし、古川注 5) らは、農山村の高齢者のつ きあいが、空間・年齢・世帯類型・つきあいの内容において広がり を持つことを明らかにした。また、寺川注 6) らは高齢者が地域で暮 らし続けるための課題を抽出し、生活面および情緒面でのサポート の必要性を説いた。高齢者生活の観点から、コミュニティの継続の 重要性を指摘した優れた研究であるが、研究の蓄積は十分とはいえ
ないのが現状である。

本稿では、道下の高齢者支援ネットワークの実態を明らかにし、 居住継続の観点より考察する。農山漁村における高齢者居住福祉、 世帯数維持・コミュニティ維持を考える上で、本研究は意義を持つ と考える注 7)。

\section{2. 高齢者支援ネットワークについて}

\section{2－1．高齢者支援ネットワーク１～～親族による支援}

輪島市都市整備課の住宅被害・復興状況に関する行政資料と筆者 らの現地調查を照合し、道下の世帯主の年齢や家族数、後継者の居 住地等に着目した世帯別の特徵や住宅復興・生活復興の実態を把握 した。結果、震災直後には娘や息子のもとや仮設住宅で避難生活を おくっていた高齢者も、大多数が元の住宅に戻ってきており、地域 外に移転したものは 3 戸に過ぎなかった注 8 。 震災後も道下に居住す る高齢者 9 名に生活支援に関するインタビュー調査を行った。後述 するが道下には高齢者が集まる交流拠点の住宅（道下区長が、「たま り場」と表現していたことから、以下では交流拠点住宅を「たまり 場住宅」と呼ぶ。）が複数存在し、今回の調査はその一住宅に集まっ た 9 名に協力いただいた。ここでは、まず日常及び緊急時に支援を してくれる人について尋㸚た（2009 年 8 月 2 日実施）注9)。 高齢世帯を物理的に支援するのは親族・親戚である場合が多く、 その居住地は, (1)集落内（道下）の親族、(2)門前町内の親族、(3)石川
* 神戸市役所 修士 (工学)

** 神戸大学大学院工学研究科 准教授 · 博士 (工学)
Kobe City Government Office, Master of Engineering

Assoc. Prof., Graduate School, Kobe University, Doctor of Engineering 
県内の親族、の 3 つに分かれた (表 1 参照)。ここでいう物理的支援 とは、家事の手伝いや介護・身の回りの世話など労働力を提供する ものを指す。生活する上で「頼りになる人がいる」ということは高 齢者にとって精神的にも大きな助けとなっている。また支援者はほ とんどが娘で、道下のものが多いことがわかった。

また、高齢住民にとって、盆・正月の親族の帰省は大きな意味を 持っていることがわかった。日常的には高齢者が多い集落であるが、 盆・正月の時期になると子どもや棌ら親族が多く帰省する。道下在 住の男性は「孫たちが盆・正月に帰ってくるのは大きな楽しみ。孫 たちが帰省寸るまでは元気でいないといけない、と考える高齢者が 多い。集落内に元気な高齢者が多いのはその影響もあるのでは」と 語った。親族・親戚の存在が、物理的にも精神的にも高齢者の生活 を支援していると考えられる。

震災後に住宅を新築した高齢独居女性 S さんの住宅は、親族の帰 省を前提とした平面計画であった。旧来の母屋は昭和 6 年に建てら れた木造 2 階建ての比較的大規模なものであったが、新築母屋は木 造平屋の小規模なものである。しかし、単に小規模化したのではな く、親族が帰省した際に寝室として用いる広間（11 畳半・和室）や 布団を収納する納戸が設けられている (図 1 参照)。実際、2008 年 正月には 10 人の親族が $\mathrm{S}$ さん宅に宿泊した。（広間 6 人、DK1 人、 納戸 1 人、寝室 2 人) 住宅復興の大工の手配から工事中の世話まで すべて道下に住む娘夫婦が行ったが、最終の間取りの決定には県外 に出ている長男や他の兄弟の意見も入っているということだった。 高齢者が集落内で生活し続ける上で、親族による支援ネットワーク が果たす役割は大きいことが確認できた。

\section{2-2. 高齢者支援ネットワーク 2 〜友人間における支援}

道下には、高齢者（主に女性）が日常的に交流を求めて集まる“た まり場” 住宅が複数存在する。特定の住民宅に複数の高齢女性が集

表 1 親族による高齢世带支援

\begin{tabular}{|c|c|c|c|c|}
\hline 高齢世帯 & 世帯構造 & 世帯主年齢 & 支援者 & 分類 \\
\hline 住民 a & 独居 & 80 & 娘 (道下) & \multirow{3}{*}{ 集落内親族 } \\
\hline 住民 b & 独居 & 88 & 娘 (道下) & \\
\hline 住民 c & 夫婦のみ & 73 & 姉妹 (道下) & \\
\hline 住民 d & 独居 & 73 & 娘 (門前町) & 門前町内親族 \\
\hline 住民 $\mathrm{e}$ & 独居 & 82 & 娘 (金沢市) & \multirow{5}{*}{ 県内親族 } \\
\hline 住民 f & 夫婦のみ & 77 & 息子(金沢市) & \\
\hline 住民 g & 夫婦のみ & 69 & 子供(金沢市) & \\
\hline 住民 h & 夫婦のみ & 74 & 子供(金沢市) & \\
\hline 住民i & 夫婦のみ & 75 & 子供 (かほく市) & \\
\hline
\end{tabular}

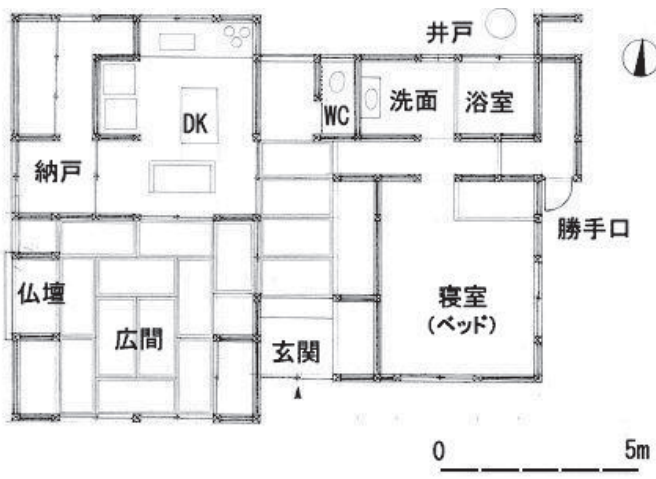

図 1 親族の帰省を前提とした $\mathrm{S} さ ん$ 宅の平面図
まり、お茶を飲んだり世間話をしたりして過ごす。このようなたま り場住宅は集落内に複数存在し、集まりはほぼ毎日午前中に行われ る。(現地でのヒアリング調查により、道下集落内にはたまり場住宅 が 8 箇所存在することがわかった。盆や正月など親族の帰省時期に は集まらない。)たまり場住宅の世帯主は独居の高齢女性であること が多く、日常生活の中で話し相手を求めている状況、友人を家に招 きやすい状況に起因寸ると考えられる。

集落内の友人との交流は、高齢者の日常生活に潤いを与えている。 しかし、緊急時などの困ったときに友人を頼りにすることはあまり ないと、たまり場住宅に集まる住民は語る。困った際に頼るのはあ くまで親族であり、友人とは一定の距離を保ちながら交流をしてい

表 2 たまり場住宅の世帯主と集まる住民

\begin{tabular}{|c|c|c|c|c|c|c|}
\hline & & 性 & 年 & 町内会 & 家族構成 & 備考 \\
\hline \multirow{9}{*}{ たまり場 I } & 世帯主 & 女 & 82 & 東町 & 独居(1) & Tさん \\
\hline & 住民 1 & 女 & - & 元町 & 夫婦(2) & - \\
\hline & 住民 2 & 女 & 88 & 東町 & 独居(1) & - \\
\hline & 住民 3 & 女 & 77 & 東町 & 独居(1) & - \\
\hline & 住民 4 & 男 & 75 & 中町 & 夫婦(2) & $\mathrm{T}$ さん親戚 \\
\hline & 住民 5 & 女 & 77 & 北町 & 夫妇(2) & - \\
\hline & 住民 6 & 女 & 73 & 北町 & 夫婦(2) & - \\
\hline & 住民 7 & 女 & - & 北町 & 子供夫婦同居(4) & - \\
\hline & 住民 8 & 女 & 78 & 大蔵町 & 独居(1) & - \\
\hline \multirow{6}{*}{ たまり場 II } & 世帯主 & 女 & 80 & 宮町 & 独居(1) & - \\
\hline & 住民 9 & 女 & 77 & 元町 & 夫婦(2) & - \\
\hline & 住民 10 & 女 & 80 & 鉄川町 & 夫婦(2) & - \\
\hline & 住民 11 & 女 & 75 & 中町 & 子供夫婦·孫と同居 & - \\
\hline & 住民 12 & 女 & 72 & 中町 & 子供夫婦·孫と同居 & - \\
\hline & 住民 13 & 女 & 87 & 宮町 & 子供夫婦·孫と同居 & - \\
\hline \multirow{9}{*}{ たまり場吕 } & 世帯主 & 女 & 72 & 北町 & 独居(1) & - \\
\hline & 住民 14 & 女 & 74 & 東町 & 夫婦(2) & - \\
\hline & 住民 15 & 女 & 70 & 東町 & 夫妇(2) & - \\
\hline & 住民 16 & 女 & 69 & 東町 & 夫婦(2) & - \\
\hline & 住民 17 & 女 & 73 & 中町 & 独居(1) & - \\
\hline & 住民 18 & 女 & 69 & 中町 & 夫婦·義父(3) & - \\
\hline & 住民 19 & 女 & 77 & 北町 & 独居(1) & - \\
\hline & 住民 5 & 女 & 77 & 北町 & 夫婦(2) & - \\
\hline & 住民 6 & 女 & 73 & 北町 & 夫婦(2) & - \\
\hline \multirow{6}{*}{ たまり場 $\mathrm{N}$} & 世帯主 & 女 & 83 & 西町 & 独居(1) & - \\
\hline & 住民 20 & 女 & 88 & 西町 & 子供夫婦と同居(3) & - \\
\hline & 住民 21 & 女 & 80 & 西町 & 子供夫婦と同居(4) & - \\
\hline & 住民 22 & 女 & 75 & 西町 & 夫婦(2) & - \\
\hline & 住民 23 & 女 & 75 & 西町 & 夫婦(2) & Vの世帯主 \\
\hline & 住民 24 & 女 & - & 西町 & 夫婦(2) & - \\
\hline \multirow{4}{*}{ たまり場 V } & 世帯主 & 女 & 75 & 西町 & 夫婦(2) & - \\
\hline & 住民 25 & 女 & 80 & 元町 & 子供夫婦·孫之同居 & - \\
\hline & 住民 20 & 女 & 88 & 西町 & 子供夫婦と同居(3) & - \\
\hline & 住民 26 & 女 & 83 & 西町 & 独居(1) & IVの世帯主 \\
\hline \multirow{5}{*}{ たまり場VI } & 世帯主 & 女 & 78 & 大蔵町 & 子供夫婦と同居(3) & - \\
\hline & 住民 27 & 女 & 75 & 西町 & 独居(1) & - \\
\hline & 住民 28 & 女 & 86 & 大蔵町 & 独居(1) & - \\
\hline & 住民 29 & 女 & 72 & 大蔵町 & 夫婦(2) & - \\
\hline & 住民 30 & 女 & 72 & 栄町 & 夫婦(2) & - \\
\hline \multirow{2}{*}{ たまり場VII } & 世帯主 & 女 & 90 & 宮町 & 独居(1) & - \\
\hline & 住民 31 & 女 & 75 & 宮町 & 子供夫婦と同居(3) & - \\
\hline たまり場VIII & 世帯主 & 女 & 65 & 東町 & 独居(1) & - \\
\hline
\end{tabular}




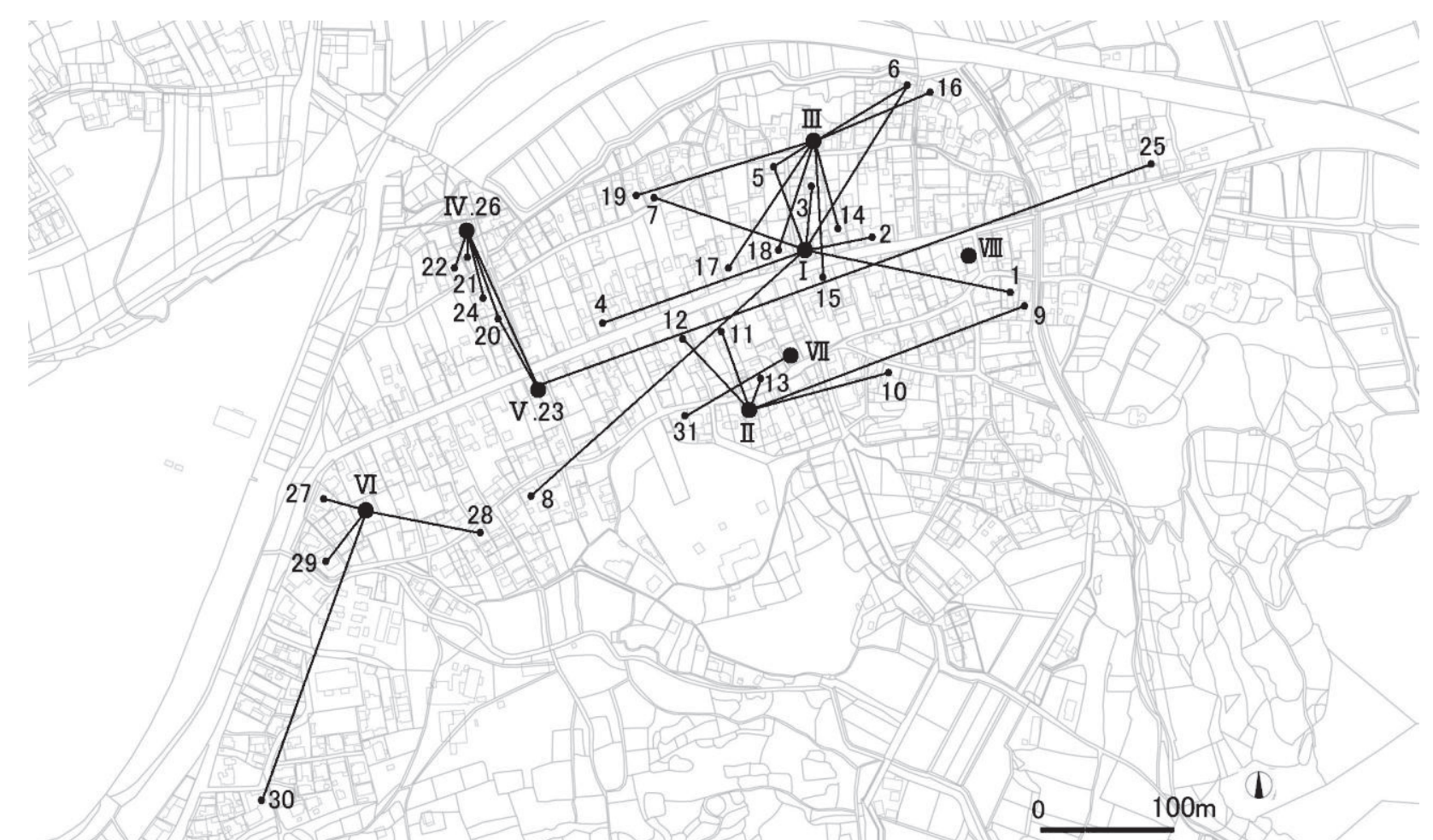

図中の数は、表に示すたまり場住宅·住民の居住地と対応する。

図 2 “たまり場”住宅が構成する友人間支援ネットワーク

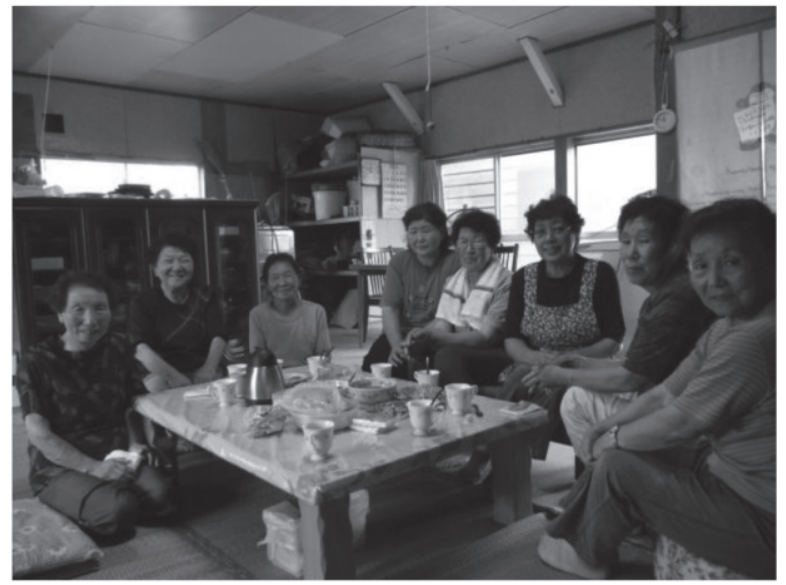

写真 1 Tさん宅に集まる住民たち（2009 年 8 月 2 日撮影）

ることがわかった。友人間の交流は、高齢世帯にとって精神的な支 援ネットワークと言える。

図 2、表 2 は、住民からのヒアリング結果を元に“たまり場”住 宅を拠点とした支援ネットワークの状況を表したものである。I 〜 VIIIは、“たまり場”住宅を表し、1～31 はそこに集まる住民宅を表し ている。基本的には、たまり場住宅とその近隣の住民らによって各 ネットワークが構成されるが、別の町内会から訪れる高齢者もおり、 町内会の地縁関係のみに縛られていないことがわかる。たまり場住 宅は集落全体に分布しており、そこを拠点とした支援ネットワーク が複数重なり合うことで、集落全域を覆っていることがわかる。

“たまり場”住宅の事例紹介（高齢独居女性 Tさん宅）

82 歳の独居女性 Tさん宅は、たまり場住宅のである（写真 1 、図
3 参照)。Tさんは剣地(道下の南部に位置する集落)出身であるが、 54 歳の頃道下に移住し以来 28 年間住み続けている（10 年ほど前に 夫が他界し、以来一人暮らしである)。15 年ほど前より、集落内の 友人たちが Tさん宅に日常的に集まり始め、住民交流の拠点となっ た。Tさん宅を訪れる友人の顔ぶれは、集まり始めた当時から殆ど 変わらない。友人 $5 \sim 8$ 名がほぼ毎日午前中 (10～12 時) に集まり、 お茶を飲みながら世間話を楽しむ。(お茶や菓子は主に T さんが用意 するが、互いに持ち寄ることも多い。）Tさん宅に集まる高齢住民の 殆どは施設サービスを利用していない。これは、たまり場住宅がデ イサービスセンターの代替機能を有しているとも考えられる。

震災の際 Tさん宅は全壊し、旧来の母屋は取り壊された。もとも と離れとして使用していた棟を改装し、居住しているが、現在も友 人らが集まるための部屋は確保されていた。このことからも、友人 同士の集まりが Tさんにとって、大きな意味を持つことが窺える。

\section{2-3． 高齢者支援ネットワーク 3 ～民生委員による支援}

民生委員が中心となって取り組む高齢者支援サービスの存在も大 きい。そのひとつとして、要援護者マップを元にした高齢世帯の見 回り活動がある。要援護者マップとは寝たきり高齢者や独居高齢者 世帯を色分けして地図上に示したもので、福祉サービスとしての見 回り活動や緊急時の安否確認に用いるため、石川県が作成を推進し た（平成 8 年に作成され、以後、毎年 12 月に更新される)。道下の 民生委員が所有する要援護者マップには、75 歳以上の独居高齢者の 世帯と 80 歳以上の高齢夫婦世帯がマークされている(写真 2 参照)。 図 4 は、要援護者マップを元に、高齢世帯の分布を表したものであ る。75 歳以上の独居高齢世帯は 56 世帯、80 歳以上の高齢夫婦世帯 は 45 世帯にのぼり、集落全体に分布している。見回り活動は月 4 


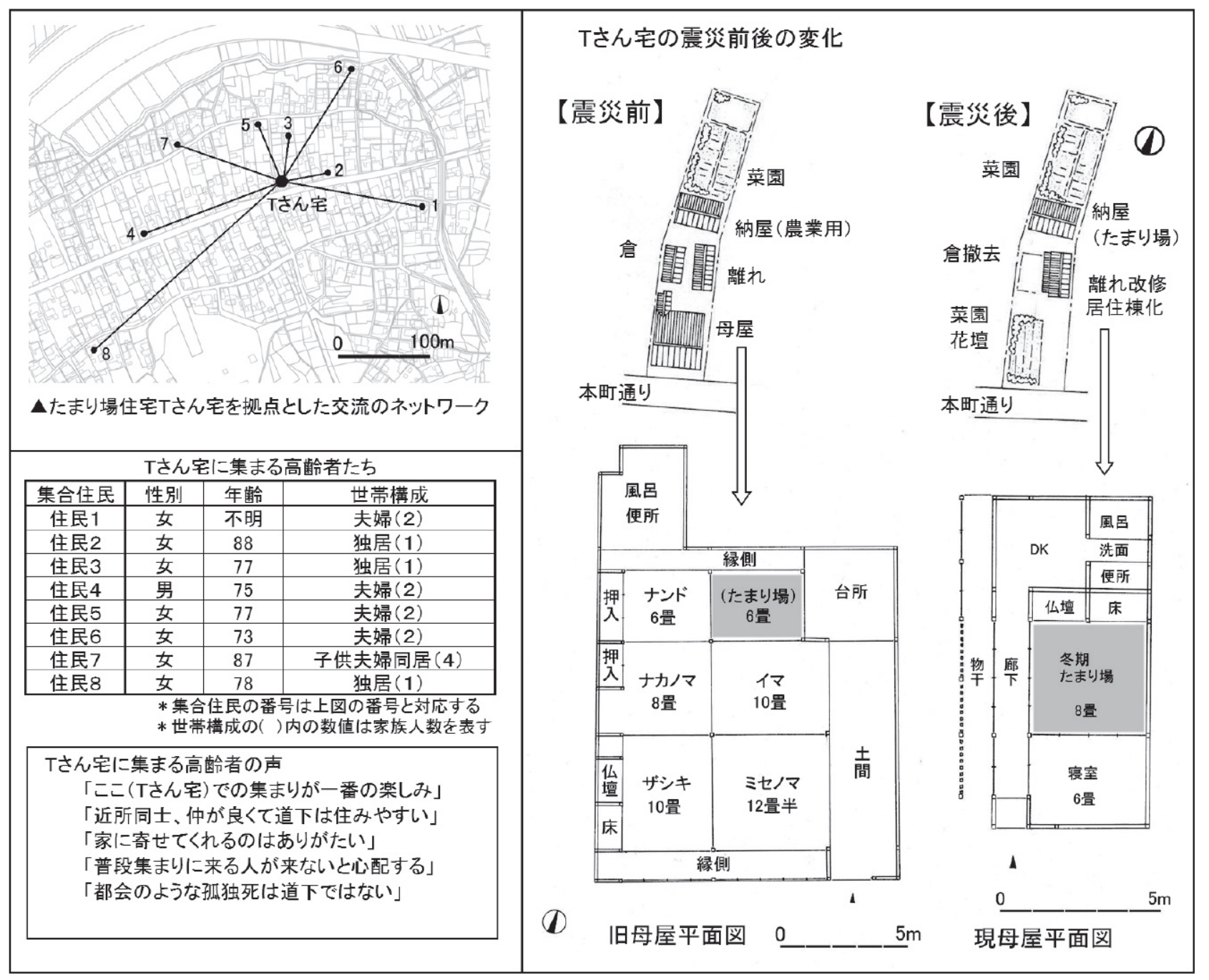

図 3“たまり場”住宅 Tさん宅について

回のペースで、道下集落内の民生委員 3 名と福祉推進員 13 名が分担 して行う（集落を東部・中部・西部の 3 地区に分け、1 地区に 1 名 の民生委員が配置、その元に福祉推進員 3〜6 名が配置される) (図 5 参照)。震災時の高齢者の安否確認にも、日頃の見回り活動が役立 ったと、民生委員 T 氏は語る。

また他の取り組みとしては、民生委員と福祉推進チームが行う高 齢世帯を対象とした配食サービスがある。2 ケ月に 1 回、75 歳以上 の独居世帯と 80 歳以上の高齢夫婦世帯に昼食が届けられるサービ スであり、食材費などにおいて輪島市から金銭的な援助がある。

民生委員の支援ネットワークは、集落全体をカバーするものであ り、公的支援体制の側面が強い。しかし、民生委員や福祉推進員自 身も高齢化しており、世代交代が課題となっている。民生委員 T氏 は「かつては民生委員というのは名誉職であったが、現在はなり手 がいない。自分たちの後の世代に仕事を引き継ぐことができるのか 心配だ」と語り、高齢者支援の持続に不安を感じている。

2-4. 高齢者支援ネットワーク 4 〜福祉施設の支援サービス

道下集落周辺には特別養護老人ホームやケアホームなど福祉施設 が 3 件存在しており、施設の支援サービスを受けやすい環境にある (特別養護老人ホームが 2 件、ケアセンターも兼补備えたグループ ホームが 1 件)。道下集落の中にもデイサービスやショートステイ、

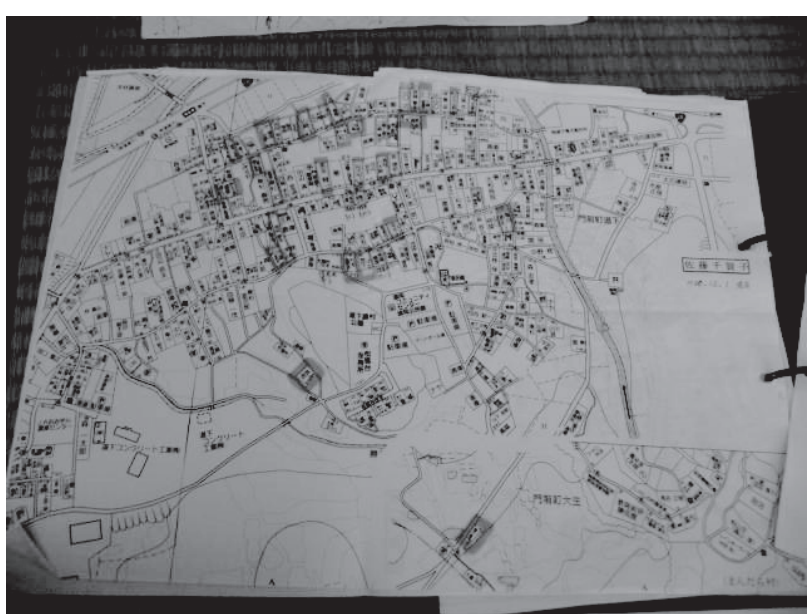

写真 2 民生委員が所有する要援護者マップ

配食サービス等のサービスを利用する住民は多く、日常的・定期的 にこのようなサービスを受けている高齢世帯もあれば、親族による ケアが困難な時のみ利用する世帯もある。道下集落には 100 歳を越 える独居高齢者が 1 名存在する。この高齢者の場合 1 个月の内、半 月は特別養護老人ホームで過ごし、もう半月は都市部に住む娘の生 
活支援を受けながら自宅で過ごしている。福祉施設のサービスと親 族による支援を使い分け、集落と繋がりを持ち続けている事例だと 位置づけられる。

\section{3. 居住継続の観点からの考察}

高齢者支援ネットワークを高齢世帯の居住継続の観点より考察す る。高齢世帯が集落内で居住し続けるためには「困ったときに頼れ
る人がいる」ことが、大きな前提となる。親族による支援ネットワ ークは単に物理的支援だけではなく、精神的支援の側面も併せ持つ、 居住継続の不可欠な要素と言える。

友人間の支援ネットワークは、物理的支援というよりも精神的支 援の側面が強い。友人による支援が与える、情緒の安定や仲間に属 することの安心感、生き甲斐（日常の楽しみ）が、高齢者に集落で の居住継続を選択させると考えられる。

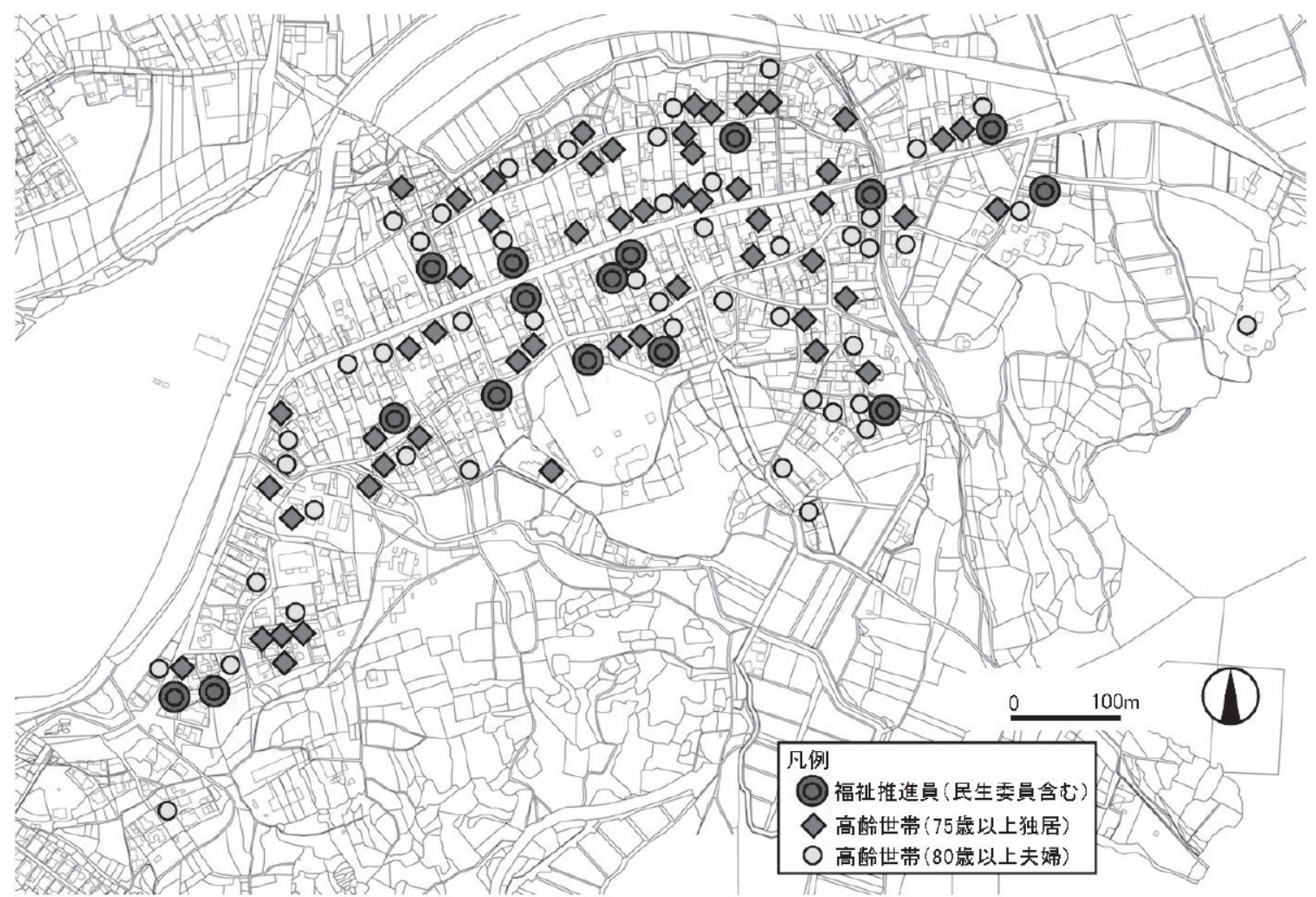

図 4 高齢世帯と福祉推進員の分布状況（民生委員所有の「要援護者マップ」を元に作成）

\begin{tabular}{|c|c|c|c|c|}
\hline $\begin{array}{l}\text { 民生委員 } \\
\text { (兼福祉推焦員) }\end{array}$ & - & 4 & & \multirow{2}{*}{ 計 } \\
\hline 福祉推進員 & मேम & போட் & பम口 & \\
\hline $\begin{array}{c}\text { 担当 } \\
\text { 福祉推進員数 }\end{array}$ & $\begin{array}{c}\text { 4名 } \\
\text { 民生委員1名) }\end{array}$ & $\begin{array}{c}\text { 7名 } \\
\text { (民生委員1名) }\end{array}$ & $\begin{array}{c}5 \text { 名 } \\
\text { (民生委員1名) }\end{array}$ & $\begin{array}{c}16 \text { 名 } \\
\text { (民生委員3名) }\end{array}$ \\
\hline $\begin{array}{c}\text { 高齡独居世帯 } \\
\text { (75歳以上) }\end{array}$ & 17世帯 & 22世帯 & 17世帯 & 56世帯 \\
\hline $\begin{array}{l}\text { 高齢夫婦世帯 } \\
\text { (80歳以上) }\end{array}$ & 14世帯 & 16世帯 & 16世帯 & 46世帯 \\
\hline 計 & 31世帯 & 38世帯 & 33世帯 & 102世帯 \\
\hline & $\begin{array}{l}\text { ※高齡方 } \\
\text { 要援言 }\end{array}$ & $\begin{array}{l}\text { - 高齢夫婦世 } \\
\text { プより計上 }\end{array}$ & & 委員所持の \\
\hline
\end{tabular}

図 5 福祉推進員の高齢世帯支援状況

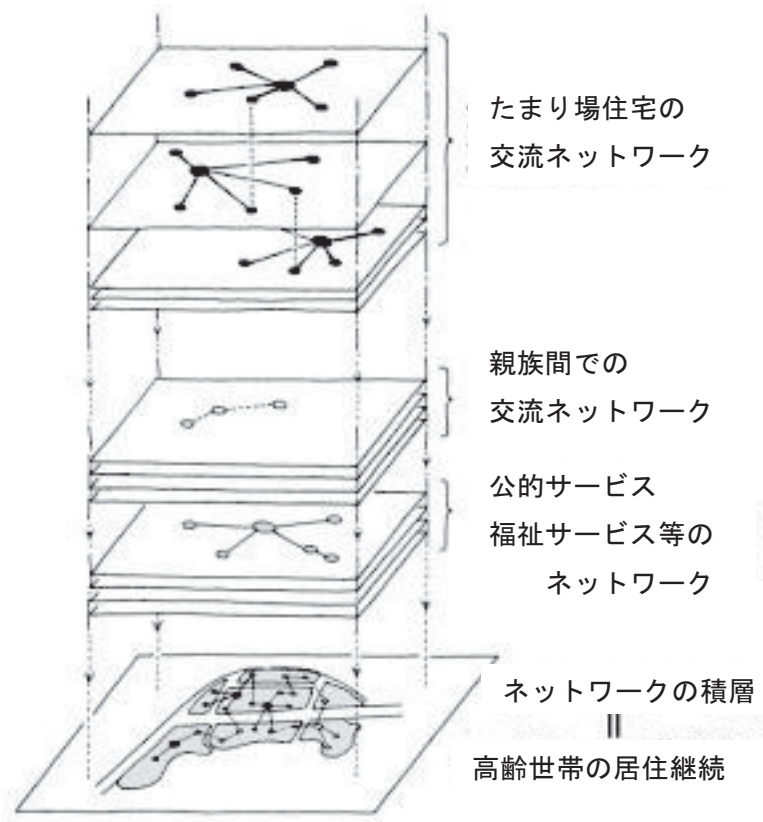

図 6 高齢者支援ネットワーク積層のモデル 
高齢者が集落内での居住を継続するためには、物理的支援・精神 的支援どちらも不可欠である。道下の場合、これらを親族による支 援と友人間の支援が主にカバーし、民生委員の支援、福祉施設のサ ービスが補助する役割をもつ。

支援ネットワークを複合させて利用寸る高齢者は、地元出身者が 多い。集落内に居住する親族・親戚の存在、近隣住民とのつきあい に代表される地域との繋がりの強さが支援の複合選択を可能にして いると考えられる。親族による支援、友人間の支援、民生委員によ る支援など、複数の支援ネットワークが積層する集落環境が高齢世 帯の居住継続要因のひとつになっている可能性が高い。(図 6 参照)。

\section{4. まとめ}

今回の研究により以下のことがわかった。

・高齢世帯の生活を支援するのは、主として親族である。特に同一 集落内に居住する娘が多い。

・親族による支援は物理的支援と精神的支援の両方の側面を持つ。 ・高齢者（主に女性）が日常的に交流を求めて集まる “たまり場” 住宅が集落内に複数存在し (8 ヶ所確認)、友人間の支援ネットワー クを形成している。

・ “たまり場”住宅は、福祉施設やコミュニティ施設の役割を担って おり、その部屋の確保は震災後の住宅復興にも配慮された。

・友人間の支援は精神的支援の側面が強い。

・緊急時や困った時に、高齢世帯が支援を求めるのは親族・親戚で あり、友人間での物理的支援は見られない。

・民生委員による高齢世帯の支援活動には、見回り活動と昼食の配 食サービスがあり、集落全体をカバーしている。

・集落環境は複数の支援ネットワークが積層する構造を内在させて おり、高齢世帯の居住継続要因のひとつになっている可能性が高い。 高齢者世帯でも安心して居住できる環境が整備されているという ことは、集落維持にとって大きな支えとなる。過疎・高齢化による 限界集落問題の解決が叫ばれる昨今、道下のような複数の高齢者支 援ネットワークの積層は、問題解決のひとつのモデルとなるであろ う。しかし、道下も今後安泰という訳ではない。10 年後あるいは 20 年後に現在と同じ世帯数を維持するため、世帯（家）の世代交代が 大きな課題として残っている。

能登半島地震の最大の被災集落である道下の震災復興において、 被災高齢者のグループホームの建設や、高齢者のたまり場となるコ ミュニティ施設の建設が検討された。しかし実現されなかった。公 的な高齢者福祉や居場所・住宅の確保は重要な政策課題といえるが、 道下にみられた高齢者の支援ネットワークやたまり場住宅の存在と いった地域で生み出された居住継続を支える英知の存在を高く評価 し、それを活用・発展させた総合的な居住継続施策の構築も重要な 計画課題・政策課題だといえる。

研究課題としては、複数の支援ネットワークが居住継続という時 間軸の中、どのような濃淡で高齢者に影響を与えるのか明らかにす ることが挙げられ、今後継続的な調查が必要である注 ${ }^{10)}$ 。また、今 回はたまり場住宅に集まる高齢者を対象に調査・研究を進めたが、 たまり場住宅へ集まらない高齢者の支援体制や公的サービスによる 支援状況など、全高齢者の生活実態の把握については現在検討・調 查中であり、今後の課題である。

\section{謝辞}

本研究を行うにあたり、輪島市門前町諸岡地区道下区の泉靖郎区 長をはじめ調査に協力いただいた諸岡地区の皆様、民生委員、福祉 推進委員の方々、震災以降の住宅復興情報を提供くださった輪島市 都市整備課、石川県建築住宅課に多大なるご協力を戴いた。記して 謝意を表する次第である。また本研究は、平成 21 年度文部省科学研 究費補助金挑戦的萌芽研究「中山間被災地域の「居住福祉」成立条 件に関する挑戦的研究」(課題番号：21656143、研究代表者 早川和 男、分担者 山崎寿一) の研究成果の一部であることを記しておく。

注

注 1) 道下集落を対象とした被災集落調查、震災復興調査は 1 回調査（2007 年 5 月、震災 1 ヶ月)、第 2 回（2007 年 9 月、震苂 6 ケ月）、第 3 回 (2007 年 11 月、諸岡地区住まい・まちづくり協議会設立 1 ケ月)、第 4 回 (2007 年 12 月、正月前)、第 5 回（2008 年 4 月、震苂 1 年）、第 6 回（2008 年 8 月、震災 1 年 6 ケ月)、第 7 回 (2009 年 1 月、震災 1 年 6 ケ月調査の 補足)、第 8 回 $(2009$ 年 3 月、震災 2 年)、第 9 回 (2009 年 4 月、震災 2 年 2 次)、第 10 回 (2009 年 7 月 8 月、震災 2 年 4 ケ月、夏祭り調查) を実施。第 1 回調查は、日本建築学会農村計画委員会 (伊藤庸一委員長) として実施した視察。他は、神戸大学山崎研究室としての調査である。 また 2009 年から、高齢者の居住継続条件の解明を目的とした調査を、平 成 21 年度文部省科学研究費補助金挑戦的萌芽研究「中山間被災地域の 「居住福祉」成立条件に関する挑戦的研究」としてスタートさせている。

注 2) 上記注 1)の第 1 回から 10 回の調査結果の一部は参考文献 1) 2) 3)4)に発 表している。参考文献 1) 2) では道下集落の地域性と震災復興、住宅復興 プロセスについて報告している。

注 3) 参考文献 3) 参照。ここでは輪島市の旧村集落を単位とした 1960 年、2005 年人口・世帯数変化を分析し、旧門前町諸岡地区およびその中心集落で ある道下の特徴を明らかにしている。

注 4) 登張絵夢・竹宮健司・上野淳 : 農山村地域にみる高齢者の生活と地域の 関係に関寸る事例的研究 : 高齢者の生活における「地縁」に関する試論, 日本建築学会計画系論文集 (540), pp. 125～132, 2001.2

注 5) 古川惠子・友清貴和 : 高齢・過疎地域における高齢者の生活を支えるつ きあいの広がりに関する研究, 日本建築学会計画系論文集 (568), pp. 77〜 84, 2003.6

注 6) 寺川優美・田中紀之・三浦研・寺川政司：豪雪・過疎地域における在宅 高齢者の人的交流に関寸る研究 : 高齢者の居住継続成立要件に関寸る研 究（その 1 ）, 日本建築学会計画系論文集 (571), pp69～76, 2003、9

注 7) 早川和男、居住福祉資源発見への旅 II（東信堂、2008.3）参照。

注 8) 参考文献 1) 参照。

注 9) 本稿では、2009 年 8 月の高齢世帯 9 名、たまり場住宅 8 ケ所（たまり場 住宅利用者 39 名）の調査結果について整理、報告したものである。ここ で紹介する被験者は、たまり場住宅 T さん宅に日常的に集まる高龃者た ちである。2010 年 1 月時点で道下集落での調査は継続しており、ヒアリ ング対象者は延べ 50 名を超えている。また全世帯を対象とした生活実態 生活復興の実態把握を行っているが、その成果は別途報告予定である。

注 10) 査読者からの指摘を踏まえ、今後の研究課題とする。

\section{参考文献}

1) 山崎寿一：能登半島地震被災集落・道下の地域性と震災復興，日本建築学 会計画系論文集 74(649)，pp. 2617～2626，2009. 12

2) 中川和樹・山崎寿一・金斗煥 : 敷地条件との関連からみた住宅復興と敷地 利用パターン一輪島市門前町諸岡地区道下の場合一, 日本建築学会住宅系 研究報告 3 , pp. 125 132，2008. 12

3) 金斗煥・山崎寿一：能登半島地震被災地域における過疎化と集落特性一旧 村集落を単位とした 1960 年、2005 年人口・世帯数変化に着目して一, 日本 建築学会近畿支部研究報告集. 計画系 No. 49, pp. 233〜236, 2009.6

4) 中川和樹：農村における高齢者の居住継続と生活支援ネットワーク一能登 半島地震被災集落・道下を事例として一, 神戸大学大学院工学研究科平成 21 年度修士論文, 2010.2 